\title{
Leaders Of Modern Anthropology
}

Charles Wagley, General Editor

Adventurous explorers in an unknown world of strange places, strange world views, and strange customs, the leaders of modern anthropology gave us new perspectives on every kind of man and way of living.

Now for the first time, a series of books is to be devoted to the careers and writings of this extraordinary group of scholars. Each book will be approximately 200 pages in length, and will be published in an inexpensive paperback edition for classroom use as well as in regular cloth binding. Each will contain: a lengthy biographical essay and critical appraisal of the subject's work by a distinguished contemporary scholar and a selection of excerpts from the subject's writings.

The series of volumes will provide both a comprehensive exposition of the fundamental ideas of modern anthropology and a unique look at what the anthropologist's work consists of, by introducing the absorbing personalities, diverse experiences, and illuminating ideas of the men and women who laid the foundations for the modern science of man.

\section{Now ready}

Ralph Linton by Adelin Linton and Charles Wagley

Alfred V. Kidder by Richard B. Woodbury

Alfred Kroeber by Julian $H$. Steward

Robert Lowie by Robert F. Murphy

\section{Forthcoming volumes}

Ruth Benedict by Margaret Mead

Franz Boas by Alexander Lesser

Melville Herskovits by George E. Simpson

E. A. Hooton by Harry L. Shapiro

Bronislaw Malinowski by Ashley Montagu

Robert Redfield by Charles Leslie

W. H. R. Rivers by Richard Slobodin

Edward Sapir by Mary R. Haas

Benjamin Whorf by Dell H. Hymes

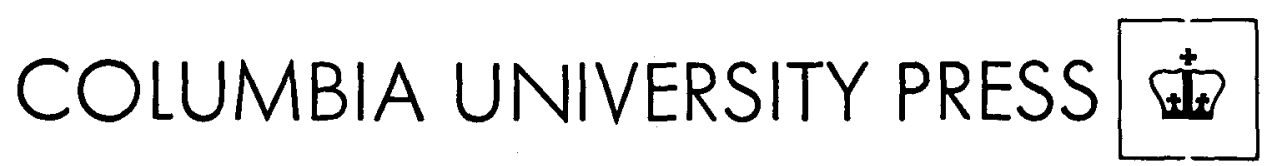




\section{PUBLICATIONS OF THE SOCIETY FOR AMERICAN ARCHAEOLOGY}

Send orders for AMERICAN ANTIQUITY, Archives of Archaeology, Memoirs, and 30-Year Index according to information given below. For publications available from the Society for American Archaeology, the address is 1703 New Hampshire Ave., N.W., Washington, D.C. 20009. Remittance must accompany orders. The publications of the Society are not available for exchange.

\section{american antiquity}

A quarterly review of American Archaeology, edited by EDWIN N. WILMSEN (University of Michigan).

Back issues are to be purchased from Kraus Reprint, 16 East 46th Street, New York, N.Y. 10017. Reprinted issues currently available are:

Vols. 1 to 20 (paperbound-\$20 per volume).

Vols. 1 to 20 (paperbound-\$400 complete).

Vols. 1 to 20 (clothbound- $\$ 460$ complete).

Volumes 21 to 33 are also available, some from the remaining inventory of the original issue. Prices for these volumes are available on request from Kraus Reprint.

Volumes 34 through 37 are available from the Society for American Archaeology. \$5.00 per copy (members $\$ 3.50$ ).

\section{MEMOIRS OF THE SOCIETY FOR AMERICAN ARCHAEOLOGY}

Occasional publications of monograph length, edited by H. MARTIN WOBST (University of Massachusetts). Memoirs 1-17 are available from Kraus Reprint. Individual members of the Society for American Archaeology are entitled to a 25 percent discount from Kraus (membership must be noted on order).

The following Memoirs are available from the Society for American Archaeology:

18. Issaquena: An Archaeological Phase in the Yazoo Basin of the Lower Mississippi Valley. ROBERT E. GREENGO. xviii+128 pages, 44 figures, 85 -tables. 1964. $\$ 4.50$ (members $\$ 2.00$ ).

19. Contributions of the Wetherill Mesa Archaeological Project, assembled by DOUGLAS OSBORNE and edited by BERNARD S. KATZ. xviii+230 pages, 154 figures, 28 tables. 1965. $\$ 7.50$ (members $\$ 4.00$ ).

20. Preliminary Report on the Ruins of Ake, Yucatón. LAWRENCE ROYS and EDWIN M. SHOOK. $\mathrm{x}+54$ pages, frontis., 62 figures. 1966 . $\$ 2.00$ (members $\$ 1.50$ ).

21. Archaeological Survey of Northern Georgia With A Test of Some Cultural Hypotheses. ROBERT WAUCHOPE. xxxii+482 pages, 258 figures, 52 tables. $1966 . \$ 12.50$ (members $\$ 6.00$ ).

22. The Arnapik and Tyara Sites: An Archaeological Study of Dorset Culture Origins. WLLIAM E. TAYLOR, JR. xiii+129 pages, 27 figures, 23 tables. 1968. $\$ 4.50$ (members $\$ 2.00$ ).

23. The Browne Site: Early Milling Stone Horizon in Southern California. ROBERTA S. GREENWOOD. ix +72 pages, 34 figures, 12 tables. $1969 . \$ 3.00$ (members $\$ 2.00$ ).

24. Archaeology at Hatchery West. LEWIS R. BINFORD and SALLY R. BINFORD, ROBERT WHALLON, MARGARET ANN HARDIN. vii+91 pages, 23 figures, 36 tables. 1970. \$3.50 (members \$2.50).

25. Approaches to the Social Dimensions of Mortuary Practices. JAMES A. BROWN, ed. vi+120 pages, 35 figures, 63 tables. 1971. $\$ 4.50$ (members $\$ 2.00$ ).

26. The Olsen-Chubbuck Site: A Paleo-Indian Bison Kill. JOE BEN WHEAT. $\mathrm{x}+180$ pages, 47 figures, 23 tables. 1972. $\$ 5.50$ (members $\$ 3.00$ ).

27. Demographic Models for Anthropology. KENNETH M. WEISS. ix+186 pages, 6 figures, 25 tables, 3 appendices. 1973. $\$ 5.50$ (members $\$ 3.00$ ).

30-YEAR INDEX, VOLUMES 1-30

Issued as AMERICAN ANTIQUITY, Vol. 37, No. 3, Pt. 2. 1972. $\mathrm{i}+189$ pages. $\$ 5.00$ (members \$3.50).

\section{ARCHIVES OF ARCHAEOLOGY}

Publication of new items in this series ceased in 1971. The Archives contain a Microcard record of primary documentation of archaeological investigations and related materials pertaining to the New World, edited by DAVID A. BAERREIS. Order from the University of Wisconsin Press, 430 Sterling Court, Madison, Wisconsin 537.01. Remittance should accompany order. A list of available publications appears in AMERICAN ANTIQUITY 34:364 (1969). 


\section{CONTENTS}

Professional Responsibilities and the American Indian

Elden Johnson

\section{ARTICLES}

Limitations of Archaeological Inference: An Information-Theoretic Approach with Applications in Methodology

Cognitive Models for Archaeological Interpretation

John S. Justeson

An Empirical Test for Steward's Model of Great Basin Settlement Patterns

Alice B. Kehoe and Thomas F. Kehoe

\section{REPORTS}

An Archaeological Indicator of Matrilocal Versus Patrilocal Residence Prehistoric Human Occupations of the Western Venezuelan Llanos The Localization of the Sixteenth Century Map Called the Maguey Plan Trilobal Eccentrics at Teotihuacan and Tula The Life Style of El Tajin Terrance L. Stocker and Michoel W. Spence Paula H. Krotser and G. R. Krotser

Melvin Ember Alberta Zucchi Edward E. Calnek

\section{COMMENT}

A Rapid Chemical Field Test for Archaeological Site Surveying Extreme Closeup Photography and Photomacrography Edge Abrasion During Biface Manufacture The Use of Water and Water Pumps in Archaeological Excavations Arrow Points or Knives? Comments on the Proposed Function of "Stockton Points" Thomas R. Hester and Robert F. Heizer

The Evidence for Complex Exchange Systems among the Ancient Maya Comment on Pickersgill's "Cultivated Plants as Evidence for Cultural Contacts"
Robert C. Eidt David Sanger Payson D. Sheets Richard G. Sense Marshall Joseph Becker Stephen C. Jett
206 210 215 218

\section{REVIEWS}

Lindsay, Jr., Ambler, Stein, and Hobler: Survey and Excavation North and East of Navajo Mountain, Utah, 1959-1962

Shay: The Itasca Bison Kill Site: An Ecological Analysis William D. Lipe Frederick Gorman W. Raymond Wood Don E. Dumond VanStone and Townsend: Kijik: An Historic Tanaina Indian Settlement

VanStone: Akulivikchuk: A Nineteenth Century Eskimo Village on the Nushagak River, Alaska

Don E. Dumond

Smith: Painted Ceramics of the Western Mound at Awatovi George J. Gumerman Jon Muller Hill: Broken K Pueblo: Prehistoric Social Organization in the American Southwest Gumerman: Black Mesa: Survey and Excavation in Northeastern Arizona, 1968 Bryan: Archaeological Explorations on San Nicolas Island W. James Judge Calvin Jennings Watkins: The Cultural History of Marlborough, Virginia. An Archeological and Historical Investigation of the Port Town for Stafford County and the Plantation of John Mercer, Including Data Supplied by Frank M. Setzler and Oscar H. Darter Leland J. Abel Navarrete: The Chiapanec History and Culture 